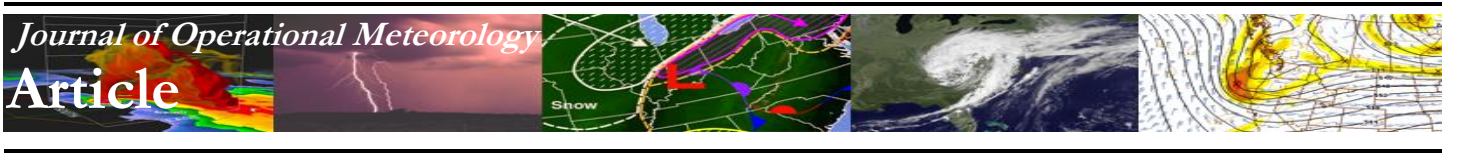

\title{
A GIS-Based Assessment of Lake-Effect Snow Warnings in Upstate New York
}

\author{
KEITH D. JASZKA \\ Weather Routing, Inc., Glens Falls, New York \\ DAVID A. CALL \\ Ball State University, Muncie, Indiana
}

(Manuscript received 4 October 2013; review completed 21 February 2014)

\begin{abstract}
Lake-effect snow (LES) occurs downwind of the Great Lakes every late autumn and winter. This phenomenon often generates significant localized snowfall that can cripple one section of a community while the remainder is spared. Detrimental impacts on travel from snowfall rates of $\geq 2.5 \mathrm{~cm} \mathrm{~h}^{-1}\left(1 \mathrm{in} \mathrm{h}^{-1}\right)$ are not uncommon. Storm-total snowfall gradients of $\geq 12.5 \mathrm{~cm} \mathrm{~km}^{-1}\left(8 \mathrm{in} \mathrm{mi}{ }^{-1}\right)$ also have been documented.

Twenty-four-hour snowfall measurements taken by National Weather Service (NWS) observers during Lake Ontario LES events were collected. Utilizing a geographic information system, snowfall was interpolated from spotter reports with the kriging method. Then, the area of warning-criteria snowfall was compared to the area of the corresponding county-based LES warning for calculation of false alarm percentage. This warning performance evaluator identified the proportion of a county-based LES warning that received sub-warning-criteria snowfall. Percent of false alarm was calculated using temporally comparable snowfall reports and all available reports from each event.

A total of 13 events from the 2009-2010 through 2011-2012 LES seasons were analyzed. The average percent of false alarm was approximately $90 \%$. This suggests the NWS should consider smaller warning polygons. Limited-size warnings would enable meteorologists to provide greater specificity regarding the location of anticipated significant snowfall, while simultaneously reducing the number of people who are unnecessarily warned.
\end{abstract}

\section{Introduction}

Every late autumn and winter, lake-effect snow (LES) disrupts the livelihoods of those who reside in the lee of the Great Lakes. During this period, the Great Lakes often are considerably warmer than the overlying air. Consequently, the bodies of water become sources of heat and moisture (i.e., instability). LES storms often generate significant snowfall that can cripple one section of a community, while the remainder is spared.

When cold air crosses the relatively warm Great Lakes and triggers LES, there often is a temperature difference of $\geq 13^{\circ} \mathrm{C}$ between the lake surface and the air at $850 \mathrm{hPa}$ (Niziol 1987). The degree of lakeinduced instability, along with the height and strength of a capping inversion, greatly influence the intensity of LES (Niziol et al. 1995). Byrd et al. (1991) con- ducted mobile soundings of LES in western and central New York and concluded that the temperature difference of $13^{\circ} \mathrm{C}$ is valid for predicting the onset of lake-effect convection. However, the correlation between the temperature difference and the intensity of lake-effect precipitation was unclear. Their soundings showcased a positive correlation between boundary layer depth (i.e., capping inversion height) and lakeeffect precipitation intensity because a higher capping inversion permits the formation of deeper lake-effect clouds capable of producing heavier snow.

A fetch (i.e., distance air travels over open water) of $\geq 80 \mathrm{~km}$ is necessary for the formation of lake-effect flurries, whereas a minimum fetch of $160 \mathrm{~km}$ is required for significant LES. Thus, not all lakes are capable of producing lake-effect precipitation (Meted 
2012). However, significant LES can be generated by smaller lakes (e.g., the Finger Lakes of New York) under certain environmental conditions (Laird et al. 2009). Wind direction at a particular level (e.g., 850 $\mathrm{hPa}$ ) can be used to determine fetch when directional shear is subtle or absent in the boundary layer (Niziol 1987; Meted 2012). However, wind direction may vary within the lake-effect cloud layer, and directional shear $>30$ degrees is detrimental to a lake-effect storm owing to entrainment. As a result, Great Lakes' forecasters often use mean-wind direction between the surface and $700 \mathrm{hPa}$ to predict the location and orientation of LES (Niziol 1987).

As described by Niziol et al. (1995), LES often consists of one or more mesoscale bands of training snow squalls. Type I LES is a single snowband that often is $20-50-\mathrm{km}$ wide and $50-200-\mathrm{km}$ long. Single LES bands form when airflow is parallel or nearly parallel to the major axis of the lake. Type II LES comprises multiple snowbands that are generated by cold air flowing perpendicular or nearly perpendicular to the major lake axis. Each band typically is $5-20-\mathrm{km}$ wide and $20-50-\mathrm{km}$ long. During an LES storm, detrimental impacts on travel are not uncommon as snowfall rates often are $\geq 2.5 \mathrm{~cm} \mathrm{~h}^{-1}\left(1 \mathrm{in} \mathrm{h}^{-1}\right)$ (Call 2005). Additionally, significant storm-total snowfall gradients have been documented. For example, in early December 2010, intense LES downwind of Lake Erie deposited $10 \mathrm{~cm}$ (4 in) of storm-total snowfall at City Hall in Buffalo, New York, while only $1.3 \mathrm{~km}(0.8 \mathrm{mi})$ to the south-southeast, $30 \mathrm{~cm}$ (12 in) of snow fell, for a corresponding gradient of approximately $15 \mathrm{~cm} \mathrm{~km}^{-1}$ (10 in $\mathrm{mi}^{-1}$ ) [National Weather Service (NWS) 2013a].

Numerous locations downwind of the Great Lakes exhibit average annual snowfall $>150 \mathrm{~cm}$ (60 in), while average annual snowfall $>250 \mathrm{~cm}$ (100 in) occurs in many of the snow belts (i.e., favored areas for LES). These snow belts exist east and southeast of the lakes owing to the prevalence of west-northwest flow accompanying cold-air outbreaks (Kristovich and Steve 1995). Of all the NWS weather forecast offices (WFOs) in the Great Lakes region, only the Buffalo, New York, WFO keeps a thorough LES event archive that is available to the public. In addition, unlike shallow Lake Erie, which may freeze over completely, Lake Ontario remains primarily ice-free during a given winter season (Niziol et al. 1995), resulting in a greater number of LES storms for analysis. Hence, the focus area (see Fig. 1) consists of Lake Ontario and the county warning area (CWA) of the Buffalo WFO, in addition to the New York state portions of the CWAs belonging to the WFOs in Albany and Binghamton, New York, and Burlington, Vermont.

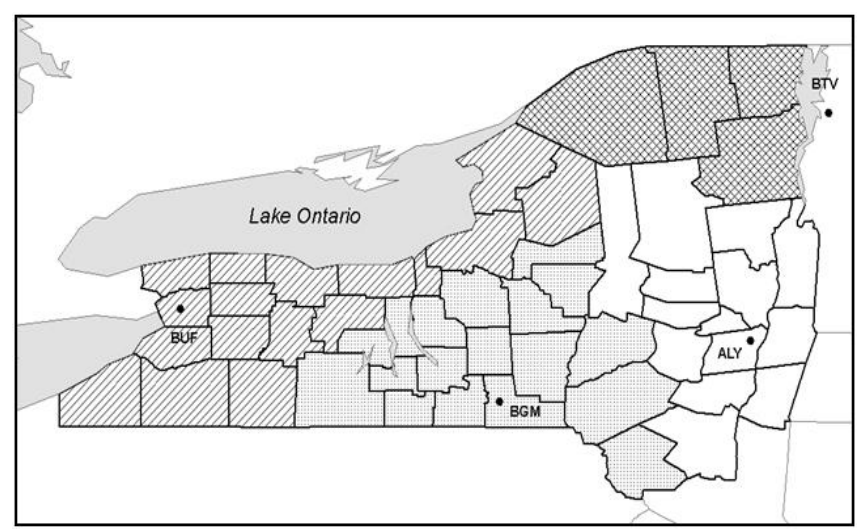

Figure 1. Focus area, WFO locations, and respective county warning areas [Albany (ALY) is white; Binghamton (BGM) is stippled; Burlington (BTV) is crosshatched; and Buffalo (BUF) is hatched]. Click image for an external version; this applies to all figures hereafter.

Previous literature regarding snowfall mapping is limited and primarily highlights average monthly-toannual snowfall (e.g., Perry and Konrad 2006; LópezMoreno et al. 2007). However, Boney and Christy (2012) demonstrated the use of geographic information system (GIS) technology to map snowfall from multiple LES events downwind of Lake Michigan. Similarly, this study utilized GIS software to compare county-based LES warning size to the extent of snowfall from multiple storms downwind of Lake Ontario.

In order to account for the small scale of particular hazardous weather phenomena, the NWS began its nationwide implementation of storm-based warnings (SBWs) on 1 October 2007. SBWs replaced the county-based warnings (CBWs) previously issued for severe thunderstorms, tornadoes, and flash floods. These SBWs are computer-drawn polygons outlined by NWS meteorologists and are defined by the latitude and longitude that correspond to the vertices of a polygon. SBWs highlight those areas under the greatest threat instead of encompassing entire counties during what are often microscale or mesoscale (i.e., $\sim 1-10 \mathrm{~km}$ ) weather events [National Oceanic and Atmospheric Administration (NOAA (2008].

Previous literature regarding CBWs and SBWs also is limited and pertains primarily to severe thunderstorm and tornado warnings. Browning and Mitchell (2002) calculated the probability of detection (POD; ratio of warned events to all events) and the false alarm ratio (FAR; ratio of unverified warnings to all warnings) for a composite of severe thunderstorm 
and tornado warnings issued by the Pleasant Hill, Missouri, WFO in April-July 2001. POD was significantly lower and FAR was slightly greater for SBWs compared to CBWs (POD: $73 \%$ versus $86 \%$; FAR: $34 \%$ versus $32 \%$ ). Waters (2007) calculated POD for all tornado warnings issued in the United States during 2005 and obtained similar results to Browning and Mitchell (2002). According to Waters (2007), the POD for tornado SBWs was significantly less than that for CBWs (57\% versus 76\%). During 2008, which was the first full year of the nationwide use of convective SBWs, the FAR was approximately $75 \%$ for tornado warning polygons (Brotzge et al. 2011). The same authors noted that all tornado CBWs issued by the NWS during 2000-2004 yielded a similar FAR of $72 \%$. Therefore, the primary trade-off of severe thunderstorm and tornado warning polygons is the reduction in warned area and the number of people who are needlessly warned at the expense of an increased potential of an unwarned severe weather event.

MacAloney (2008) developed a verification metric known as percent of event warned (PEW) for flashflood SBWs. The flash-flood area is defined using the latitude, longitude, and time of the first flood report through the latitude, longitude, and time of the last report associated with a particular flash-flood event. It is then assumed flooding occurred over the entire area during the entire time period. MacAloney (2008) calculated the PEW both spatially and temporally. The estimated area of the flash flood was compared to the area of its SBW and the temporal length of the flood was compared to the temporal length of the SBW. POD for flash-flood warning polygons is the PEW for each individual event during a time period (e.g., one year) divided by the total number of flash-flood events. The FAR for flash-flood SBWs is the number of unverified warnings divided by the total number of warnings. POD ranged from 75 to $82 \%$ and FAR ranged from 41 to $49 \%$ for flash-flood SBWs issued during 2008-2012 (B. MacAloney 2013, personal communication). These verification statistics indicate flash-flood SBWs performed quite well, which suggests SBWs are valid for other localized hydrologic events (e.g., LES).

\section{Data and methods}

An LES warning is issued by the WFOs in Albany, Binghamton, and Buffalo when $\geq 17.8 \mathrm{~cm}$ ( 7 in) of new snow are expected in $12 \mathrm{~h}$, or $\geq 23 \mathrm{~cm}$ (9 in) are expected in $24 \mathrm{~h}$. The Burlington WFO issues an
LES warning when $\geq 15 \mathrm{~cm}$ (6 in) of snow are expected in $12 \mathrm{~h}$, while its 24-h snow-warning threshold is the same as those of the other three WFOs (NWS Eastern Region Headquarters 2013, personal communication; see Fig. 2). During a winter storm, a snow spotter may measure 24-h snowfall at their regularly scheduled observation time and then submit their report to their local WFO. Snow spotters also are encouraged to measure snow every $6 \mathrm{~h}$, beginning with their regularly scheduled observation time. Other spotters may measure snowfall once snow has ended and prior to melting and/or compaction (NWS 1997). Because all snow spotters do not measure snowfall simultaneously, there are inconsistencies among snowfall reports.

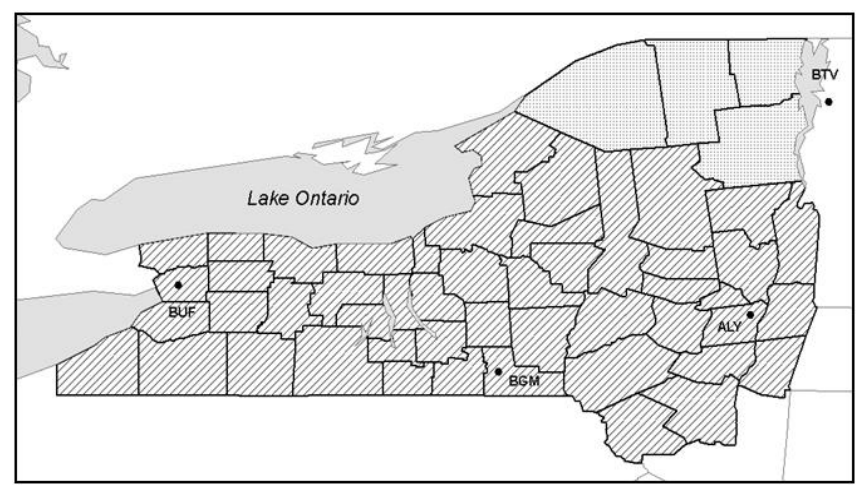

Figure 2. Twelve-hour snow-warning thresholds [stippled is 15.0 $\mathrm{cm}$ (6.0 in); hatched is $17.8 \mathrm{~cm}$ (7.0 in)]. The 24-h snow-warning threshold is $23 \mathrm{~cm}$ (9.0 in) throughout the focus area.

The LES storm archive kept by the Buffalo WFO (NWS 2013b) was used to identify significant LES storms downwind of Lake Ontario during the 200910, 2010-11, and 2011-12 snow seasons based on storm-total snowfall and storm duration. Archived NWS text products (mesonet.agron.iastate.edu/wx/ afos/list.phtml) were then used to assemble warning and snowfall data from all significant storms during the aforementioned snow seasons. A total of 16 warned storms occurred during the time period. However, all multi-day LES storms were divided into 24-h segments because most NWS spotters report snowfall once daily. As a result, a database of 38 warned LES events was obtained. Public information statements issued by each affected WFO that displayed the greatest number of 24-h snowfall measurements were used to gather reports for each of the 38 LES events. However, only 13 of the 38 warned LES events were analyzed because of snowfall data issues. These issues included snowfall reports explicitly labeled as 
Table 1. General information about each LES event studied, including the number of warning-criteria snowfall (WCS) reports and predominant storm type (Type I is single band and Type II is multiband).

\begin{tabular}{|c|c|c|c|c|c|c|c|}
\hline $\begin{array}{c}\text { LES } \\
\text { Event } \\
\text { Label } \\
\end{array}$ & $\begin{array}{l}\text { Mode of 24-h Snow- } \\
\text { fall Measurement } \\
\text { Times and Dates }\end{array}$ & $\begin{array}{c}\text { Estimated } \\
\text { Area Affected } \\
\left(1000 \mathbf{k m}^{2}\right) \\
\end{array}$ & $\begin{array}{c}\text { Maximum } \\
\text { Snowfall }(\mathrm{cm})\end{array}$ & $\begin{array}{l}\text { Range of Top 25\% } \\
\text { Snow Amounts (cm) }\end{array}$ & $\begin{array}{c}\text { Total } \\
\text { Reports }\end{array}$ & $\begin{array}{l}\text { WCS } \\
\text { Reports }\end{array}$ & $\begin{array}{c}\text { Predominant } \\
\text { Storm Type }\end{array}$ \\
\hline Feb-10 & $\begin{array}{c}1200 \text { UTC } \\
1 \text { February } 2010 \\
\end{array}$ & 16.1 & 33.3 & $18.8-33.3$ & 13 & 3 & Type I \\
\hline Nov-10 & $\begin{array}{c}1200 \text { UTC } \\
27 \text { November } 2010\end{array}$ & 5.7 & 26.3 & $13.8-26.3$ & 5 & 1 & Type I \\
\hline Dec-10A & $\begin{array}{c}1200 \text { UTC } \\
6 \text { December } 2010\end{array}$ & 50.0 & 34.5 & $14.3-34.5$ & 63 & 5 & Type II \\
\hline Dec-10B & $\begin{array}{c}1200 \text { UTC } \\
15 \text { December } 2010\end{array}$ & 48.4 & 31.3 & $14.8-31.3$ & 43 & 4 & Type II \\
\hline Dec-10C & $\begin{array}{c}1200 \text { UTC } \\
16 \text { December } 2010\end{array}$ & 42.0 & 44.5 & $15.8-44.5$ & 69 & 7 & Type II \\
\hline Jan-11A & $\begin{array}{c}1200 \text { UTC } \\
\text { 16 January } 2011\end{array}$ & 45.8 & 23.8 & $10.0-23.8$ & 57 & 2 & Type I \\
\hline Jan-11B & $\begin{array}{c}1200 \text { UTC } \\
17 \text { January } 2011\end{array}$ & 15.8 & 48.0 & $15.5-48.0$ & 17 & 1 & Type II \\
\hline Jan-11C & $\begin{array}{c}1200 \text { UTC } \\
\text { 22 January } 2011\end{array}$ & 17.1 & 42.3 & $18.0-42.3$ & 13 & 3 & Type I \\
\hline Feb-11A & $\begin{array}{c}1200 \text { UTC } 10 \\
\text { February } 2011\end{array}$ & 9.8 & 27.5 & $13.0-27.5$ & 9 & 1 & Type I \\
\hline Feb-11B & $\begin{array}{c}1200 \text { UTC } \\
11 \text { February } 2011\end{array}$ & 8.5 & 38.8 & $19.5-38.8$ & 7 & 2 & Type I \\
\hline Nov-11 & $\begin{array}{c}1200 \text { UTC } \\
18 \text { November } 2011\end{array}$ & 13.5 & 32.3 & $12.8-32.3$ & 35 & 7 & Type I \\
\hline Dec-11 & $\begin{array}{c}1200 \text { UTC } \\
11 \text { December } 2011 \\
\end{array}$ & 4.1 & 26.3 & $25.0-26.3$ & 5 & 2 & Type I \\
\hline Jan-12 & $\begin{array}{c}1200 \text { UTC } \\
\text { 31 January } 2012\end{array}$ & 6.2 & 75.8 & $13.8-75.8$ & 17 & 4 & Type I \\
\hline
\end{tabular}

being associated with time periods other than $24 \mathrm{~h}$ (e.g., 12- and 18-h reports), including those from warned counties. In addition, no public information statements regarding snowfall were available from the Burlington WFO when it issued an LES warning. Table 1 displays the 13 LES events included in this study.

The 24-h snowfall measurement time varied among spotters. In order to obtain $24-\mathrm{h}$ snowfall reports that were temporally comparable, the mode of all available 24-h snowfall measurement times from each of the 13 LES events was found. Once the mode was identified (1200 UTC for all 13 events), only snowfall measurements taken within $1 \mathrm{~h}$ of the mode (i.e., from 1100 to 1300 UTC) were used as input for mapping LES. This accounted for differences in measurement time among snow spotters and allowed each snowfall map to correspond to a discrete time period (i.e., $\sim 1200$ to 1200 UTC the following day). Also, temporally comparable $24-\mathrm{h}$ snowfall reports of a trace [i.e., $<0.25 \mathrm{~cm}$ of snow $(<0.1$ in of snow)] were not included.
Because public information statements do not include the latitude and longitude of snow-spotter reports, an archive of hydrologic reports (hurricane.ncdc. noaa.gov/pls/plhas/has.dsselect) was used to obtain the coordinates of each 24-h snowfall measurement. The WFOs in Albany and Binghamton routinely issued hydrologic reports during all 13 LES events, while the Buffalo WFO did not. When hydrologic reports from the Buffalo WFO were unavailable, snow-spotter locations were obtained from public information statements, and then Google Earth (www. google.com/earth/) was implemented to obtain the latitude and longitude of each 24-h snowfall measurement. In some cases, public information statements displayed multiple temporally comparable 24-h snowfall measurements from the same location when the corresponding hydrologic reports were unavailable. The solution was to always use the 24-h snowfall measurement with the greatest value. If it was impossible to find the coordinates of a particular snow-spotter report using Google Earth, the latitude and longitude data were provided by WFO Buffalo. 


\section{a. LES mapping and analysis}

After the database of snowfall measurements was created, several geographical and mathematical adjustments were made to prepare the data for mapping. First, archived radar data (locust.mmm.ucar.edu/) were used to determine where LES occurred during each event. Then, multiple locations, including several upwind of Lake Ontario (e.g., Hamilton and Toronto, Ontario), were added to each of the 13 datasets and assigned an initial value of zero. This allowed for the creation of snowfall maps that essentially tapered to zero. Next, the skewness of 24-h nonzero snowfall measurements was calculated to determine the normality of each dataset. All 13 LES event datasets were positively skewed to some degree. Oliver and Webster (1990) state that skewed datasets, especially those that are strongly skewed, must be transformed logarithmically in order to stabilize the variance. Prior to transforming the data, a value of $0.25 \mathrm{~cm}(0.1 \mathrm{in})$ was added to all 24-h snowfall reports (including the zero reports), to avoid errors that would have occurred from attempting to calculate the natural $\log$ of zero. This approach mimicked one done by Boney and Christy (2012).

For each event, snowfall reports were displayed with GIS software. Then the snowfall reports were georeferenced relative to the focus area of this study in order to eventually calculate the percent of false alarm (PFA). Afterward, interpolated snowfall maps for each LES event were created with the kriging method (Oliver and Webster 1990) using an exponential model. An exponential model assumes autocorrelation disappears only at an infinite distance, and this approach is favored in the earth sciences [see Oliver and Webster (1990) for further discussion]. Autocorrelation is a spatial relationship based on the belief that measurements that are closer to one another are more alike than those that are far apart (Wilks 1995). Because 24-h snowfall measurements that shared the same LES event were used as input to create each snowfall map, the measurements were alike in that sense. Kriging accounts for the distance between snowfall data points and their spatial distribution (Oliver and Webster 1990). This allowed kriging with the exponential model to create snowfall maps that essentially emulated the location and orientation of each lake-effect event (see Fig. 3).

Once each snowfall map was created, its properties were modified. A manual classification method with five classes was used for this study. Classes

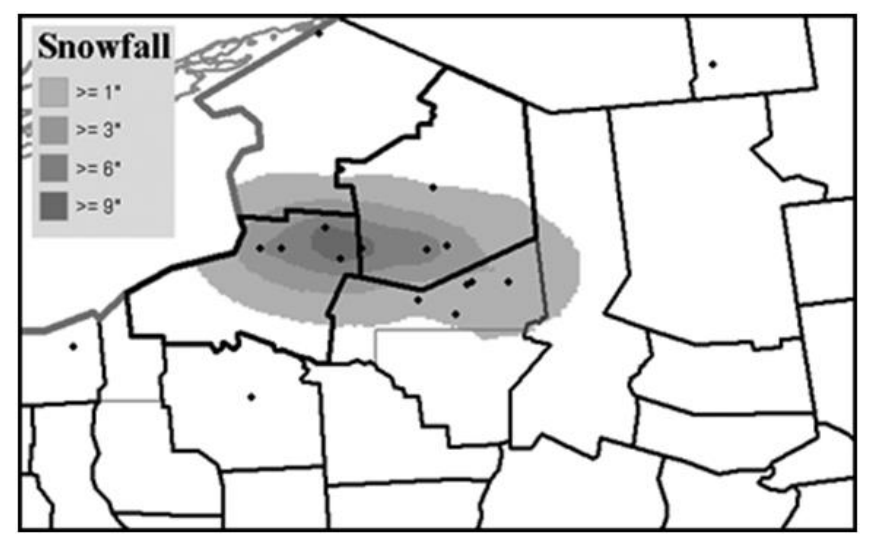

Figure 3. Kriging-generated snowfall map (shaded, in) for the Dec-11 LES event (see Table 1). This event predominately was a Type I storm triggered by a westerly flow of cold air across Lake Ontario. North is toward the top of the map. The two warned counties are bolded and black dots are snowfall data points.

1-4 were adjusted to display where $\geq 2.5,8,15$, and 23 $\mathrm{cm}(\geq 1,3,6$, and 9 in) of LES fell within $24 \mathrm{~h}$. Each snowfall map was then converted into a raster (i.e., an array of data cells). Once each LES raster was created, its properties were modified to adhere to the aforementioned manual classification scheme. Afterward, the number of warning-criteria snowfall cells [i.e., square cells with a value $\geq 23 \mathrm{~cm}$ ( 9 in) of snow] were obtained for each event. Then, snowfall cell area was multiplied by the number of warning-criteria snowfall cells in order to obtain warning-criteria snowfall area $\left(\mathrm{WCS}_{\text {area }}\right)$. Finally, PFA was calculated for each event.

\section{b. Analysis of county-based LES warnings}

The metric created to gauge the effectiveness of county-based LES warnings in this study is PFA. This warning evaluation metric is similar to PEW developed by MacAloney (2008) for flash-flood SBWs, using this formula: PFA $=\left[1-\left(\mathrm{WCS}_{\text {area }} / \mathrm{CBW}_{\text {area }}\right)\right] \times$ 100 , where $\mathrm{WCS}_{\text {area }}$ is the area of warning-criteria snowfall and $\mathrm{CBW}_{\text {area }}$ is the area of the corresponding county-based LES warning. Thus, PFA measures the percentage of a county-based LES warning that was a false alarm.

A temporal criterion was established for determining which counties should be included in the $\mathrm{CBW}_{\text {area }}$ for each event. $\mathrm{CBW}_{\text {area }}$ is the cumulative area of the counties that were under an LES warning for $\geq 8 \mathrm{~h}$ of the 24-h time period corresponding to the mode of all available 24-h snowfall measurement times from a particular event. As mentioned before, the mode of all available 24-h snowfall measurement times was 1200 
UTC for all 13 events. This temporal criterion prevented inflation of $\mathrm{CBW}_{\text {area }}$ [i.e., some counties were warned briefly $(<5 \mathrm{~h})$ when heavy LES failed to materialize]. It also accounted for the fact that snow does not always fall during an entire 24-h period. Occasionally, CBW area also included sub-county areas. The NWS divided Cayuga County, New York, into north and south because the northern (southern) portion of the county resides in the Buffalo WFO (Binghamton WFO) CWA. Oneida and Erie counties also were divided because of their geometry. In other words, all three aforementioned counties may only have their northern or southern portion included in a county-based LES warning depending on the expected location of significant LES.

\section{Analysis}

\section{a. Warning-criteria snowfall area}

As mentioned previously, 1200 UTC (0700 EST) was the mode of all 24-h snowfall measurement times from all 13 LES events (Table 1). Temporally comparable 24-h snowfall measurements were those taken within $1 \mathrm{~h}$ of the mode of all measurement times. While $>30$ temporally comparable 24 -h snowfall measurements had been submitted during some LES events, there were four events during which < 10 temporally comparable 24-h snowfall measurements were taken.

A total of nine events were predominantly Type I storms (i.e., single snowbands), and the remaining four were primarily Type II (i.e., multiband) storms (Niziol et al. 1995). Kristovich and Steve (1995) found multiband LES storms to be the most common type downwind of all five Great Lakes, while single-band storms are most frequent downwind of Lake Ontario. LES storm mode affected the spatial extent of each storm and, subsequently, the number of snowfall reports (see Table 1). Type II (multiband) snow events generally affected the largest areas and were associated with the largest number of snowfall reports; three of the four most widespread LES events were Type II. These three Type II storms deposited $\geq 2.5 \mathrm{~cm}$ ( 1 in) of snow over an estimated affected area exceeding $41440 \mathrm{~km}^{2}$ $\left(16000 \mathrm{mi}^{2}\right)$ and generated $>40$ temporally comparable snowfall reports each. On the other hand, the four events with $<10$ reports were predominately Type I storms. Table 1 also shows how the range of the top $25 \%$ snow amounts varied among the 13 LES events. Nine of thirteen LES events surpassed the 23-cm (9in) $24-\mathrm{h}$ snow-warning criterion by $\geq 7.6 \mathrm{~cm}$ ( 3 in). The greatest temporally comparable 24 -h snowfall report was $75.8 \mathrm{~cm}$ (29.8 in) from the Jan-12 event (Table 1).

Table 2. Warning-criteria snowfall area $\left(\mathrm{WCS}_{\text {area }} ; \mathrm{km}^{2}\right)$, county-based LES warning area $\left(\mathrm{CBW}_{\text {area }}\right.$; $\left.\mathrm{km}^{2}\right)$, number of counties warned, percent of false alarm (PFA), and predominant storm type for each LES event for (a) Type I storms and (b) Type II storms. "Average All” denotes the average values of $\mathrm{WCS}_{\text {area }}, \mathrm{CBW}_{\text {area }}$, and PFA for all 13 LES events (i.e., Type I and Type II storms combined).

\begin{tabular}{|c|c|c|c|c|c|}
\hline a) LES Event Label & $\mathbf{W C S}_{\text {area }}$ & $\mathbf{C B W}_{\text {area }}$ & Counties Warned & PFA & Predominant Storm Type \\
\hline Feb-10 & 1039.5 & 6565.2 & 2 & 84.2 & Type I \\
\hline Nov-10 & 15.0 & 9204.4 & 3 & 99.8 & Type I \\
\hline Jan-11A & 272.8 & 14316.1 & 5 & 98.1 & Type I \\
\hline Jan-11C & 2596.2 & 19165.4 & 11 & 86.5 & Type I \\
\hline Feb-11A & 20.6 & 9204.4 & 3 & 99.8 & Type I \\
\hline Feb-11B & 106.0 & 9204.4 & 3 & 98.8 & Type I \\
\hline Nov-11 & 755.7 & 4242.2 & 2 & 82.2 & Type I \\
\hline Dec-11 & 47.3 & 5971.9 & 2 & 99.2 & Type I \\
\hline Jan-12 & 404.3 & 3215.8 & 2 & 87.4 & Type I \\
\hline Average & 584.2 & 9010.0 & $\mathrm{n} / \mathrm{a}$ & 92.9 & Type I \\
\hline b) LES Event Label & WCS $_{\text {area }}$ & $\mathbf{C B W}_{\text {area }}$ & $\begin{array}{l}\text { Counties } \\
\text { Warned } \\
\end{array}$ & PFA & Predominant Storm Type \\
\hline Dec-10A & 2206.0 & 16556.2 & 10 & 86.7 & Type II \\
\hline Dec-10B & 489.4 & 14527.0 & 10 & 96.6 & Type II \\
\hline Dec-10C & 1549.4 & 11500.2 & 7 & 86.5 & Type II \\
\hline Jan-11B & 409.5 & 15102.9 & 8 & 97.3 & Type II \\
\hline Average & 1163.6 & 14421.6 & $\mathrm{n} / \mathrm{a}$ & 91.8 & Type II \\
\hline Average All & 762.4 & 10675.1 & $n / \mathbf{a}$ & 92.5 & All storms \\
\hline
\end{tabular}


WCS $_{\text {area }}$ differed among the 13 LES events. In regard to predominant storm type, the average $\mathrm{WCS}_{\text {area }}$ from predominantly Type I storms $\left[584.2 \mathrm{~km}^{2}(225.5\right.$ $\mathrm{mi}^{2}$ ); Table 2a] was less than that from LES events primarily in the form of a Type II storm $\left[1163.6 \mathrm{~km}^{2}\right.$ $\left(449.3 \mathrm{mi}^{2}\right)$; Table $\left.2 \mathrm{~b}\right]$. This was expected as Type II LES events often impact a larger area than Type I LES events (Niziol et al. 1995). The average $\mathrm{WCS}_{\text {area }}$ from all 13 LES events was $762.4 \mathrm{~km}^{2}$ (294.4 $\mathrm{mi}^{2}$; Table $2 b)$.

\section{b. County-based LES warning area}

The influence of predominant storm type on $\mathrm{CBW}_{\text {area }}$ was similar to that involving $\mathrm{WCS}_{\text {area }}$. Table 2a displays $\mathrm{CBW}_{\text {area }}$ and the number of counties warned for the nine predominantly Type I storms, while Table $2 b$ shows the same for LES events primarily in the form of Type II storms. When applicable, the number of warned counties included one or more sub-county portions. For example, three of the eight warned counties during the Jan-11B LES event (Table 2b) were northern Cayuga, northern Oneida, and southern Oneida counties. Type I storms prompted CBWs with an average area of $9010.0 \mathrm{~km}^{2}$ (3478.8 $\mathrm{mi}^{2}$ ). Owing to the multiband structure of Type II LES, the average $\mathrm{CBW}_{\text {area }}$ was $14421.6 \mathrm{~km}^{2}\left(5568.2 \mathrm{mi}^{2}\right)$ for such storms. The average $\mathrm{CBW}_{\text {area }}$ for all $13 \mathrm{LES}$ events was $10675.1 \mathrm{~km}^{2}$ (4121.7 $\mathrm{mi}^{2}$; Table $\left.2 b\right)$. Considering average $\mathrm{WCS}_{\text {area }}$ for all 13 LES events was $762.4 \mathrm{~km}^{2}\left(294.4 \mathrm{mi}^{2}\right)$, county-based LES warnings often are considerably larger than the area of significant snowfall.

\section{c. Percent of false alarm}

The values of PFA were larger than expected. PFA is the percentage of a county-based LES warning that received $<23 \mathrm{~cm}$ ( 9 in) of snow in $24 \mathrm{~h}$. The average PFA for Type I storms was $92.9 \%$ (Table 2a) and the average PFA for Type II storms was $91.8 \%$ (Table $2 b$ ). For all 13 LES events, the average PFA was $92.5 \%$ (Table 2b). PFA values ranged from $82.2 \%$ for the Nov-11 LES event to $99.8 \%$ for the Nov-10 and Feb11A LES events, respectively. All three LES events were predominantly Type I storms.

Because PFA values from the 13 LES events were larger than anticipated, a second set of 13 LES maps was created using all available 24 -h snowfall measurements in case the use of only temporally comparable 24-h snowfall measurements had affected the PFA results. All available 24-h snowfall measurements were those reports - regardless of measurement timethat were available from the public information statement with the most reports from a given LES event. As a result, the snowfall maps created with all available 24-h snowfall reports cover a much less definitive 24-h period. However, of the 13 LES events, there were 11 in which all available snowfall reports were measured on the same day with respect to UTC. In addition, the majority of additional snowfall reports were measured before 1200 UTC during 10 of the 13 events and these reports were measured no earlier than 0200 UTC. Finally, additional snowfall reports taken after 1200 UTC were measured $\leq 6 \mathrm{~h}$ later. Consequently, a snowfall report measured at 1800 UTC 16 January 2011 was integrated with those reports having a measurement time mode of 1200 UTC 16 January 2011. Additionally, a report measured at 0200 UTC 11 December 2011 was included with those reports having a measurement mode of 1200 UTC on the same date. The same techniques as before (section 2) were followed to collect snowfall report coordinates, interpolate the second set of 13 snowfall maps, and calculate PFA. As a result, $\mathrm{CBW}_{\text {area }}$ remained constant for each LES event, which allowed us to determine if limiting data to temporally comparable 24-h snowfall reports contributed to especially large PFA values.

For all but one event, the use of all available 24-h snowfall measurements added $\leq 10$ reports to the total number of reports as shown in Table 3 . In exception, the number of reports associated with the Dec-10C event increased from 69 temporally comparable 24-h reports to 92 total 24-h reports. For most events, the number of WCS measurements (Table 3, right column) either remained the same or increased by $\leq 3$ after all available 24-h snowfall measurements were included. However, for the Jan-11A LES event, five additional warning-criteria snowfall reports were included in the database.

Using all available 24-h snowfall measurements caused an increase or no change in $\mathrm{WCS}_{\text {area }}$ for 11 of the 13 LES events (see Table 4). For example, WCS $_{\text {area }}$ increased by $1203.8 \mathrm{~km}^{2}$ and $1549.2 \mathrm{~km}^{2}\left(464.8 \mathrm{mi}^{2}\right.$ and $598.1 \mathrm{mi}^{2}$ ), respectively, to $1224.4 \mathrm{~km}^{2}$ and 1822.0 $\mathrm{km}^{2}\left(472.7 \mathrm{mi}^{2}\right.$ and $\left.703.5 \mathrm{mi}^{2}\right)$ for the Feb-11A and Jan-11A LES events. On average, WCS $_{\text {area }}$ increased by $284.1 \mathrm{~km}^{2}\left(109.7 \mathrm{mi}^{2}\right)$. However, for two events, WCS $_{\text {area }}$ actually decreased by $17.7 \mathrm{~km}^{2}$ and $244.4 \mathrm{~km}^{2}$ $\left(6.9 \mathrm{mi}^{2}\right.$ and $\left.94.4 \mathrm{mi}^{2}\right)$, respectively, to a total of 471.7 $\mathrm{km}^{2}$ and $795.1 \mathrm{~km}^{2}\left(182.1 \mathrm{mi}^{2}\right.$ and $\left.307.0 \mathrm{mi}^{2}\right)$ for the Dec-10B and Feb-10 LES events when all available 24-h snowfall measurements were included. This is 
Table 3. Comparisons of temporally comparable snowfall reports with all available snowfall reports.

\begin{tabular}{|c|c|c|c|c|c|c|}
\hline $\begin{array}{l}\text { LES Event } \\
\text { Label }\end{array}$ & $\begin{array}{c}\text { Temporally } \\
\text { Comparable } \\
\text { Reports }\end{array}$ & $\begin{array}{c}\text { All } \\
\text { Reports }\end{array}$ & $\begin{array}{l}\text { Difference } \\
\text { in \# of } \\
\text { Reports }\end{array}$ & $\begin{array}{c}\text { Temporally } \\
\text { Comparable } \\
\text { WCS Reports }\end{array}$ & $\begin{array}{c}\text { All WCS } \\
\text { Reports }\end{array}$ & $\begin{array}{c}\text { Difference } \\
\text { in \# of } \\
\text { Reports }\end{array}$ \\
\hline Feb-10 & 13 & 16 & 3 & 3 & 4 & 1 \\
\hline Nov-10 & 5 & 8 & 3 & 1 & 2 & 1 \\
\hline Dec-10A & 63 & 70 & 7 & 5 & 8 & 3 \\
\hline Dec-10B & 43 & 46 & 3 & 4 & 4 & 0 \\
\hline Dec-10C & 69 & 92 & 23 & 7 & 8 & 1 \\
\hline Jan-11A & 57 & 66 & 9 & 2 & 7 & 5 \\
\hline Jan-11B & 17 & 20 & 3 & 1 & 1 & 0 \\
\hline Jan-11C & 13 & 16 & 3 & 3 & 5 & 2 \\
\hline Feb-11A & 9 & 14 & 5 & 1 & 3 & 2 \\
\hline Feb-11B & 7 & 9 & 2 & 2 & 2 & 0 \\
\hline Nov-11 & 35 & 43 & 8 & 7 & 8 & 1 \\
\hline Dec-11 & 5 & 14 & 9 & 2 & 4 & 2 \\
\hline Jan-12 & 17 & 23 & 6 & 4 & 6 & 2 \\
\hline
\end{tabular}

Table 4. The difference in $\mathrm{WCS}_{\text {area }}\left(\mathrm{km}^{2}\right)$ from temporally comparable and all available 24-h snowfall reports.

\begin{tabular}{|c|c|c|c|c|}
\hline LES Event Label & $\begin{array}{c}\text { Temporally Comparable } \\
\mathbf{W C S}_{\text {area }}\end{array}$ & All Reports $\mathbf{W C S}_{\text {area }}$ & Change in WCS $_{\text {area }}$ & CBW $_{\text {area }}$ \\
\hline Feb-10 & 1039.5 & 795.1 & -244.4 & 6565.2 \\
\hline Nov-10 & 15.0 & 54.9 & 39.9 & 9204.4 \\
\hline Dec-10A & 2206.0 & 2620.9 & 414.9 & 16556.2 \\
\hline Dec-10B & 489.4 & 471.7 & -17.7 & 14527.0 \\
\hline Dec-10C & 1549.4 & 1586.2 & 36.8 & 11500.2 \\
\hline Jan-11A & 272.8 & 1822.0 & 1549.2 & 14316.1 \\
\hline Jan-11B & 409.5 & 409.5 & 0.0 & 15102.9 \\
\hline Jan-11C & 2596.2 & 2791.8 & 195.6 & 19165.4 \\
\hline Feb-11A & 20.6 & 1224.4 & 1203.8 & 9204.4 \\
\hline Feb-11B & 106.0 & 112.1 & 6.1 & 9204.4 \\
\hline Nov-11 & 755.7 & 869.0 & 113.3 & 4242.2 \\
\hline Dec-11 & 47.3 & 199.1 & 151.8 & 5971.9 \\
\hline Jan-12 & 404.3 & 648.7 & 244.4 & 3215.8 \\
\hline Average & $\mathbf{7 6 2 . 4}$ & $\mathbf{1 0 4 6 . 6}$ & $\mathbf{2 8 4 . 1}$ & $\mathbf{4 1 2 1 . 6 7}$ \\
\hline
\end{tabular}

because two sub-warning-criteria snowfall reports in close proximity to warning-criteria snowfall reports from the Dec-10B event caused $\mathrm{WCS}_{\text {area }}$ to contract upon interpolation. As these two sub-warning-criteria reports were taken approximately $2 \mathrm{~h}$ after the mode of 24-h snowfall measurement times, perhaps they reflect compaction effects. $\mathrm{WCS}_{\text {area }}$ decreased for the Feb-10 event because of the inclusion of two sub-warningcriteria snowfall reports taken $9.5 \mathrm{~h}$ before nearby snowfall reports that met the warning criterion. In conclusion, including all available 24-h snowfall reports generally caused increases in $\mathrm{WCS}_{\text {area }}$ (and thus decreases in PFA), and probably increased the accuracy of most maps. However, the inclusion of all available reports may have compromised the accuracy of several snowfall maps because "incompatible" data (i.e., snowfall measurements taken $>1 \mathrm{~h}$ from the mode of measurement times) were input for interpolation.

Because the use of all available 24-h snowfall measurements increased $\mathrm{WCS}_{\text {area }}$ for 10 of the 13 LES events, PFA for those 10 LES events decreased accordingly as shown in Table 5. Note PFA decreased by 
Table 5. The changes in percent of false alarm (PFA, \%) from temporally comparable and all available 24-h snowfall reports.

\begin{tabular}{|c|c|c|c|}
\hline $\begin{array}{c}\text { LES Event } \\
\text { Label }\end{array}$ & $\begin{array}{c}\text { Temporally } \\
\text { Comparable } \\
\text { PFA }\end{array}$ & $\begin{array}{c}\text { All Reports } \\
\text { PFA }\end{array}$ & Change in PFA \\
\hline Feb-10 & 84.2 & 87.9 & 3.7 \\
\hline Nov-10 & 99.8 & 99.4 & -0.4 \\
\hline Dec-10A & 86.7 & 84.2 & -2.5 \\
\hline Dec-10B & 96.6 & 96.8 & 0.2 \\
\hline Dec-10C & 86.5 & 86.2 & -0.3 \\
\hline Jan-11A & 98.1 & 87.3 & -10.8 \\
\hline Jan-11B & 97.3 & 97.3 & 0.0 \\
\hline Jan-11C & 86.5 & 85.4 & -1.1 \\
\hline Feb-11A & 99.8 & 86.7 & -13.1 \\
\hline Feb-11B & 98.8 & 98.8 & $<0.1$ \\
\hline Nov-11 & 82.2 & 79.5 & -2.7 \\
\hline Dec-11 & 99.2 & 96.7 & -2.5 \\
\hline Jan-12 & 87.4 & 79.8 & -7.6 \\
\hline Average & $\mathbf{9 2 . 5}$ & $\mathbf{8 9 . 7}$ & $-\mathbf{2 . 8}$ \\
\hline
\end{tabular}

$<0.1 \%$ for the Feb-11B LES event. The decrease in PFA was greatest for the Jan-11A and the Feb-11A LES events. PFA decreased by $10.8 \%$ and $13.1 \%$, respectively, to $87.3 \%$ and $86.7 \%$ for the Jan-11A and Feb-11A events with the use of all available 24-h snowfall measurements. Because the use of all available 24-h snowfall measurements actually caused WCS $_{\text {area }}$ to decrease for the Feb-10 and Dec-10B LES events, the PFA increased slightly for these two events. Overall, the use of all available 24-h snowfall reports allowed the average PFA for all LES events to decrease from 92.5 to $89.7 \%$. Therefore, whether temporally comparable 24-h snowfall measurements or all available 24-h snowfall measurements were used to obtain $\mathrm{WCS}_{\text {area }}$, the percentage of each county-based LES warning that was a false alarm was considerable. Additionally, the average PFA was $89.1 \%(91.1 \%)$ for the nine predominately Type I storms (four predominately Type II storms) when snowfall was interpolated from all available 24-h snowfall reports (not shown).

\section{d. Accuracy of snowfall maps}

Kriging is an objective mapping scheme, and while we think it produced realistic snowfall maps, a more rigorous accuracy evaluation also was undertaken by examining the root mean square error (RMSE) of each map. RMSE is the square root of the sum of squared residuals divided by the number of observations. In this study, a residual was the difference between measured snowfall and interpolated snowfall at
Table 6. Root mean square errors (RMSEs; $\mathrm{cm}$ ) for all 13 pairs of snowfall maps created with kriging from temporally comparable and from all available 24-h snowfall reports.

\begin{tabular}{|c|c|c|}
\hline LES Event Label & $\begin{array}{c}\text { Temporally } \\
\text { Comparable RMSE }\end{array}$ & All Reports RMSE \\
\hline Feb-10 & 1.5 & 2.3 \\
\hline Nov-10 & 1.8 & 2.0 \\
\hline Dec-10A & 1.5 & 1.5 \\
\hline Dec-10B & 1.8 & 1.8 \\
\hline Dec-10C & 1.3 & 1.5 \\
\hline Jan-11A & 1.8 & 1.8 \\
\hline Jan-11B & 1.8 & 1.8 \\
\hline Jan-11C & 2.8 & 2.5 \\
\hline Feb-11A & 2.8 & 2.5 \\
\hline Feb-11B & 3.0 & 2.8 \\
\hline Nov-11 & 1.5 & 1.3 \\
\hline Dec-11 & 1.8 & 1.5 \\
\hline Jan-12 & 2.0 & 1.8 \\
\hline Average & $\mathbf{1 . 9}$ & $\mathbf{1 . 9}$ \\
\hline
\end{tabular}

a particular spotter's latitude and longitude. The number of observations was the total number of spotter reports (i.e., the total number of temporally comparable 24-h snowfall measurements or all available 24-h snowfall measurements) from a particular LES event. The closer the RMSE value is to zero, the more accurate the interpolated map.

RMSE values were larger than expected for the 26 LES maps created with kriging (Table 6). The relatively small number of 24-h snowfall measurements used for LES interpolation was likely the reason for the larger RMSE values. To see if another interpolation method would be more appropriate, inverse-distance weighting (IDW) was considered. IDW estimates snowfall at a particular location by considering its distance from snowfall data points. The farther a particular snowfall data point was from a given location, the less influence it had on interpolated snowfall. IDW yielded LES maps that were less accurate than those from kriging. The Wilcoxon rank-sum test (Wilks 1995) was used to statistically gauge the accuracy of a sample of snowfall maps interpolated by kriging compared with those created by IDW. The test produced a $p$ value of 0.018 . Thus, snowfall maps created with kriging were significantly more accurate than those created with IDW.

\section{Forecast implications}

Storm-based LES warnings would allow NWS meteorologists to warn the public more effectively by 
highlighting where the probability of significant snowfall is greatest. These smaller warnings also would reduce the number of people who are unnecessarily warned. LES warning polygons also would have the capability of displaying expected storm type and placement. A narrower warning would correspond to a nearly stationary or stationary single snowband, while a wider warning would indicate the expectation of a multiband storm or transient LES storm - regardless of type. Storm-based LES warnings also would be beneficial during early season events (e.g., November). In such situations, significant snow accumulation typically is confined to locations farther inland from the considerably warm lake and/or at higher elevations (e.g., the Tug Hill Plateau east of Lake Ontario).

While there are many probable advantages of LES warning polygons, potential issues exist as well. As mentioned before, the smaller size of SBWs would decrease the amount of people who are unnecessarily warned. However, the same attribute also could cause FAR to increase and POD to decrease if a SBW is offset from where significant snowfall actually occurs. In addition, deciding where to place a storm-based LES warning and determining polygon size will be challenging because of the potentially transient nature of a storm and the spatial characteristics of different LES storm types. For example, Type II storms often impact a larger area than Type I storms owing to their multiband structure (Niziol et al. 1995). Furthermore, describing the threat area verbally and concisely on NOAA Weather Radio and AM/FM radio will create difficulties similar to those with current warning polygons (Browning and Mitchell 2002). Additionally, as LES storms often can span multiple days, there may be considerable changes in warned areas on a daily basis as bands oscillate. Last, while SBWs should reduce PFA, it is likely to remain high because of forecast uncertainty, especially in situations of high wind shear or when winds are expected to vary during the event. The NWS will need to determine how to issue storm-based LES warnings if such warnings become a reality. We recommend that a pilot study be conducted in several Great Lakes region CWAs to test the validity of SBWs versus CBWs for LES. This will help the NWS determine if and how best to issue storm-based LES warnings, and also what level of benefits may be realized by a reduction in PFA.

When significant LES is possible, the NWS should continue to place entire counties under a watch because of a greater level of forecast uncertainty. Once forecast confidence increases, NWS meteorologists will be able to decide where to place a storm-based LES warning and how to orient the warning based on multiple predictors. Mean boundary-layer wind direction and fetch dictate LES storm type (Niziol et al. 1995). In addition, the direction and magnitude of mean boundary-layer flow (e.g., mean-wind direction and speed between the surface and $700 \mathrm{hPa}$ ) determine LES orientation and placement (Niziol 1987). Last, mesoscale model quantitative precipitation forecasts also are important for predicting the intensity, length, width, and placement of LES storms. Scott and Sousounis (2001) demonstrated the ability of additional sounding data from northeastern Ontario and western Quebec to improve a mesoscale model simulation of an LES storm over and downwind of Lake Michigan. Obviously, accurate forecasts of storm placement and intensity will ensure effective stormbased LES warnings.

\section{Conclusions}

A database of 24-h snowfall reports from 13 LES events was created and then snowfall maps were constructed with the kriging technique with GIS software. The interpolated snowfall maps were then compared to the areas under county-based LES warnings to calculate what percentage of the warned area was falsely warned, that is, the PFA. The average PFA was $92.5 \%$ when temporally comparable 24-h snowfall reports were used for snowfall interpolation and $89.7 \%$ when all available 24-h reports were included. The type of LES event had little effect on PFA values. For the nine predominantly Type I storms, the average PFAs were $92.9 \%$ and $89.1 \%$ for temporally comparable and all available 24-h snowfall reports, respectively. Average PFA values for the four predominantly Type II storms were $91.8 \%$ (91.1\%) for temporally comparable (all available) 24-h snowfall reports.

The primary limitation of this study was the spatial resolution of snow-spotter reports used for interpolation of LES. Interpolation tools such as kriging are optimized when the number of data points is large, the data points have a high spatial resolution, and they are evenly distributed. Owing to the localized nature of LES-among other reasons-snow-spotter reports from each of the 13 events were not necessarily numerous, did not exhibit a fine spatial resolution, and the snowfall data points were surely not evenly spaced with respect to one another. Thus, the accuracy of each interpolated LES map, including the accuracy of

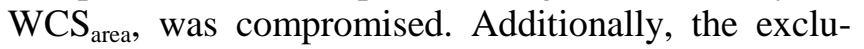


sion or inclusion of non-temporally comparable snowfall reports had some effect on the PFA calculations. Nonetheless, the effects of 24-h reports submitted at non-standard times (i.e., $>1 \mathrm{~h}$ before/after the mode of all available reports) seemed to be at the noise level. In response to reviewer comments, we reexamined radar data to see if reports from consecutive days caused a site to appear to miss warning-criteria snowfall. For example, a location received $22.5 \mathrm{~cm}$ (9 in) of snow in six consecutive hours straddling 1200 UTC, resulting in one 24-h snowfall report of $12.5 \mathrm{~cm}$ (5 in) ending at 1200 UTC and another $24-\mathrm{h}$ report of $10 \mathrm{~cm}$ (4 in) at 1200 UTC the next day. However, this reanalysis resulted in only a few additional warning-criteria reports that would not have decreased PFA significantly. Future researchers may wish to examine the issues stemming from the low temporal resolution of snowfall reports further.

In conclusion, SBWs or other warning techniques potentially could reduce PFA for LES warnings. SBWs would enable meteorologists to clearly convey where the significant snowfall threat exists and limit the number of people who are falsely warned. Nevertheless, reducing warning size requires the consideration of some temporal and spatial issues, and it could lead to an increase in instances where a location receives warning-criteria snowfall without being warned. However, we believe the benefits of adopting SBWs with regard to LES would be worth any challenges in their implementation.

Acknowledgments. The authors thank Holley Boney of Valparaiso University for recommending the kriging method for snowfall interpolation and Luigi Meccariello of NWS Albany, Michael Evans and Ron Murphy of NWS Binghamton, and David Zaff of NWS Buffalo for providing the authors with snow-spotter coordinates, hydrologic reports, and other necessary data. Last, the authors thank the anonymous reviewers for their input, which strengthened the content of this manuscript tremendously.

\section{REFERENCES}

Boney, H., and M. Christy, cited 2012: GIS mapping and analysis of lake-effect snowfall patterns in Indiana and SW Michigan. Celebration of Undergraduate Scholarship, Office of Sponsored and Undergraduate Research, Paper 136. [Available online at scholar.valpo.edu/ cgi/viewcontent.cgi? article $=1130 \&$ context=cus.]
Brotzge, J., S. Erickson, and H. Brooks, 2011: A 5-yr climatology of tornado false alarms. Wea. Forecasting, 26, 534-544, CrossRef.

Browning, P. A., and M. Mitchell, 2002: The advantages of using polygons for the verification of National Weather Service warnings. Preprints, 16th Conf. on Probability and Statistics in the Atmospheric Sciences, Orlando, FL, Amer. Meteor. Soc., JP1.1. [Available online at ams.confex.com/ams/pdfpapers/28747.pdf.]

Byrd, G. P., R. A. Anstett, J. E. Heim, and D. M. Usinski, 1991: Mobile sounding observations of lake-effect snowbands in western and central New York. Mon. Wea. Rev., 119, 2323-2332, CrossRef.

Call, D. A., 2005: Rethinking snowstorms as snow events: A regional case study from upstate New York. Bull. Amer. Meteor. Soc., 86, 1783-1793, CrossRef.

Kristovich, D. A. R., and R. A. Steve III, 1995: A satellite study of cloud-band frequencies over the Great Lakes. J. Appl. Meteor., 34, 2083-2090, CrossRef.

Laird, N., R. Sobash, and N. Hodas, 2009: The frequency and characteristics of lake-effect precipitation events associated with the New York State Finger Lakes. $J$. Appl. Meteor. Climatol., 48, 873-886, CrossRef.

López-Moreno, J. I., S. M. Vicente-Serrano, and S. Lanjeri, 2007: Mapping snowpack distribution over large areas using GIS and interpolation techniques. Climate Research, 33, 257-270, CrossRef.

MacAloney, B. W., II, 2008: Storm-based warning verification: A new era in warning verification. Preprints, 24th Conf. on Severe Local Storms, Savannah, GA, Amer. Meteor. Soc., 9A.5. [Available online at ams.confex.com/ams/24SLS/techprogram/paper_14216 0.htm.]

Meteorological Education (MetEd), cited 2012: Topics in lake effect snow forecasting. [Available online at www.meted.ucar.edu/norlat/snow/lake_effect/.]

Niziol, T. A., 1987: Operational forecasting of lake effect snowfall in western and central New York. Wea. Forecasting, 2, 310-321, CrossRef.

, W. R. Snyder, and J. S. Waldstreicher, 1995: Winter weather forecasting throughout the eastern United States. Part IV: Lake effect snow. Wea. Forecasting, 10, 61-77, CrossRef.

NOAA, 2008: Storm based warnings: A review of the first year. NOAA/NWS, Office of Climate, Water, and Weather Services Report, $12 \mathrm{pp}$. [Available online at www.wral.com/asset/weather/2008/10/15/3741623/SB W report 6.pdf.]

NWS, 1997: Snow measurement guidelines for National Weather Service cooperative observers. U. S. Department of Commerce, NOAA/NWS Office of Meteorology, $10 \mathrm{pp}$. [Available online at www.erh.noaa.gov/ er/gyx/spotters_skywarn/Snow_Measurement_Guidelin es_05-1997.pdf.]

, cited 2013a: Lake effect summary - December 1-3, 2010. National Weather Service, Buffalo, NY. 
[Available online at www.erh.noaa.gov/buf/lakeffect/ lake1011/b/stormsumb.html.]

, cited 2013b: NWS Buffalo lake effect page. National Weather Service, Buffalo, NY. [Available online at www.wbuf.noaa.gov/lakepage.php.]

Oliver, M. A., and R. Webster, 1990: Kriging: A method of interpolation for geographical information systems. Int. J. Geographical Information Systems, 4, 313-332, CrossRef.

Perry, L. B., and C. E. Konrad, 2006: Relationships between NW flow snowfall and topography in the southern Appalachians, USA. Climate Research, 32, 35-47, CrossRef.
Scott, C. P. J., and P. J. Sousounis, 2001: The utility of additional soundings for forecasting lake-effect snow in the Great Lakes region. Wea. Forecasting, 16, 448-462, CrossRef.

Waters, K. R., 2007: Verification of National Weather Service warnings using geographic information systems. Preprints, 23rd International Conf. on Interactive Information Processing Systems for Meteorology, Oceanography, and Hydrology, San Antonio, TX, Amer. Meteor. Soc., 4.B1. [Available online at ams.confex.com/ams/pdfpapers/116773.pdf.]

Wilks, D. S., 1995: Statistical Methods in the Atmospheric Sciences. Academic Press, 467 pp. 